Running Head: The LAMBI Scale

\title{
Accepted with minor revisions
}

\section{Psychology of Religion \& Spirituality}

Development and Validation of the Five-Factor LAMBI Measure of God Representations

\author{
Kathryn A. Johnson ${ }^{1}$ \\ Morris A. Okun ${ }^{1}$ \\ Adam B. Cohen ${ }^{1}$ \\ Carissa A. Sharp ${ }^{2}$ \\ Joshua N. Hook ${ }^{3}$ \\ ${ }^{1}$ Arizona State University \\ ${ }^{2}$ Newman University, UK \\ ${ }^{3}$ University of North Texas
}

Correspondence:

Kathryn A. Johnson

Psychology Department

Arizona State University

Kathryn.a.johnson@asu.edu

602-740-5616

\section{ACKNOWLEDGEMENT}

This research was conducted thanks to the generous support of the John Templeton Foundation. 


\begin{abstract}
God representations are complex and there is no standard, relatively short, and easy to administer measure reflecting both anthropomorphic and abstract representations of God. We developed a new measure with five dimensions: Limitless, Authoritarian, Mystical, Benevolent, and Ineffable (the LAMBI scale). In Study 1, we used exploratory factor analysis to examine the factor structure of a preliminary list of 41 common adjectives that people might use to describe God. In Study 2, we identified the 25 best-fitting items, using confirmatory factor analysis to show that a five-factor model fit well, and began to validate the new scale using measures of religious commitment, individualistic spirituality, and Quest. In Study 3, we found the scale has good testretest reliability. In Study 4, we examined the contribution of the LAMBI scales in predicting conservatism, values, and beliefs, above and beyond two existing measures of God representations. In Study 5, we used latent profile analysis to identify four response patterns across the five dimensions: Relational, Abstract, Unbelief, and Amorphous (no differences across the five dimensions) and show little relation between these profiles and religious group membership. We conclude that the LAMBI scale assesses important individual differences in thinking about God and can potentially be used to predict beliefs and social attitudes.
\end{abstract}

Keywords: God representations, God concepts, theism, deism, pantheism, panentheism 


\section{The LAMBI Scale:}

\section{Development and Validation of a Five-Factor Measure of God Representations}

Beliefs about God are complex and there are meaningful individual differences in the characteristics that people attribute to God (e.g., Davis, Moriarty, \& Mauch, 2013; Granqvist, Mikulincer, \& Shaver, 2010; Sharp, Rentfrow, \& Gibson, 2017). No standard measure of God representations has emerged and the majority of extant measures focus on evaluating anthropomorphic views of God as nurturing versus punishing, with only a handful of measures assessing more abstract views of God. In the present research, we develop a 25- adjective scale designed to assess both personified and abstract representations of God along five dimensions: Benevolent, Authoritarian, Limitless, Mystical, and Ineffable.

People may think of God in anthropomorphic terms, as authoritarian or benevolent (Froese \& Bader, 2010; Gorsuch, 1968; Johnson, Li, Cohen, \& Okun, 2013; Johnson, Okun, \& Cohen, 2015). Belief in a benevolent God is associated with higher self-esteem (Benson \& Spilka, 1973), a benevolent self-identity (Roberts, 1989), perceived social support from God (Fiala, Bjorck, \& Gorsuch, 2002), and religious coping (Wong-McDonald \& Gorsuch, 2004). Beliefs about the authoritarian attributes of God are associated with the value of power (Johnson et al., 2015), aggression (Bushman, Ridge, Das, Key, \& Busath, 2007), a decrease in cheating (Shariff \& Norenzayan, 2011), and struggles with God (Exline, Grubbs, \& Homolka, 2015).

Individuals may also represent God in more abstract terms. In a 2010 survey conducted by the Pew Forum on Religion and Public Life, $25 \%$ of the respondents reported belief in an impersonal force rather than a personal God, and in the 2010 General Social Survey, $15 \%$ of participants responded that God was more like a cosmic force than a personal being (which was endorsed by 68\%; Smith, 2011). In a study of Europeans, Zwingmann and Gottschling (2015) 
found that $48 \%$ of Catholics, $92 \%$ of Muslims, and $39 \%$ of the non-religious professed belief in a transcendent reality as an impersonal higher power.

When people think about God abstractly, they may use terms such as infinite (Spilka, Armatas, \& Nussbaum, 1964), conscience (Kunkel, Cook, Meshel, Daughtry, \& Hauenstein, 1999), or Life Force (Bishop, 1999). Although abstract may be less common than personal God representations, there are examples throughout the major religions. For example, the Bible describes God as I AM, Alpha and Omega, or the Holy Spirit. Muslims have 99 names for God including the Vast and the Absolute. The Jewish philosopher Martin Buber referred to God as the Eternal Thou (1986/1958), whereas Spinoza equated nature with the Divine (Nadler, 2006). Barbour (1998) reported that God has been characterized as First Cause or Logos (the Word).

These descriptors of God from psychology, world religions, and philosophy convey a divine essence or Spirit which can be known. However, God has also been described as Incomprehensible (Templeton \& Herrmann, 1989). Many Muslims would also profess that God is beyond understanding (Stark, 2007). The Jewish sage Maimonides, too, described God as beyond imagination, and many Jews today would agree (Silverman, Johnson, \& Cohen, 2016).

Indeed, no single word or psychological construct can adequately describe the many ways that people have represented the nature of God. Clearly, a single survey question regarding belief in God (e.g., "Do you believe in God") would fall short of capturing the complexities of how people represent God, a Higher Power, or Divine Life Force in their own experience. Consequently, there have been several efforts to create a measure which can capture the diversity in God representations (Hill \& Hood, Jr., 1999). We drew upon these earlier studies, discussed below, to create a 25-item multidimensional measure which assesses both personified and abstract (impersonal) representations of God, a Higher Power, or Divine Life Force. 


\section{Extant measures of God representations}

Using the psychoanalytic perspective, Rizzuto (1979) and Lawrence (1997) developed 45-item and 72-item measures, respectively, to evaluate a person's relationship with God. McCallister (1999) examined drawings of God, while others have used word lists describing God. For instance, (Vergote, et al., 1969) used a list of 18 maternal and 18 paternal descriptors to examine God images. Benson \& Spilka (1973) utilized 10 pairs of items to assess concepts of God as Loving versus Hating and Controlling versus Uncontrolling and other human traits have also been used (e.g., Cheston, Piedmont, \& Lavin, 2003; Krejci, 1998; Sharp et al., 2017).

Spilka et al. (1964) appear to be the first to assess both anthropomorphic (personified) and abstract (impersonal) concepts of God. Using a 64-adjective Q-sort task, the researchers identified 11-12 factors which they reduce to two dimensions of God concepts as a personal being (Supportive [e.g. gracious, merciful] and Punitive [e.g. punishing, stern]), and three dimensions related to abstract concepts (Omni-ness [e.g. infinite, omnipotent], Distant [e.g. inaccessible, impersonal], and Supreme Ruler [e.g. majestic, sovereign]).

Building upon Spilka et al. (1964), Gorsuch (1968) designed a more extensive 91-item measure including three evaluative domains: good/bad, strong/weak, and active/passive. In a sample of 585 undergraduates, Gorsuch also found multiple factors which he labeled Traditional Christian (e.g., forgiving, gracious), Wrath (e.g., stern, wrathful), Omni (e.g., infinite, omnipotent), Deistic (e.g., distant, inaccessible), and Irrelevant (e.g., worthless, weak), suggesting that the Omni-ness and Deistic dimensions might be particularly important to assess in terms of abstract attributes. Although the factor structure failed to replicate in subsequent research (e.g., Schaefer \& Gorsuch, 1992), the adjective list has provided material for constructing other measures as well (e.g., Wong-McDonald \& Gorsuch, 2004). 
Kunkel et al. (1999) used an 85-item card sort and survey of 20 students to develop a conceptual map of God representations with two dimensions: nurturant versus punitive and mystical versus anthropomorphic, suggesting that mystical attributes may constitute a third important abstract representation. However, adjectives along the mystical dimension measured by Kunkel et al. included disparate terms such as humorous, simple, unafraid, silent, logical, and charming, making the mystical dimension difficult to interpret.

Using a sample of 1,438 Belgians, Hutsebaut and Verhoeven (1995) developed yet another measure with 53 statements drawn partly from Vercruysse (1972). With items such as "God is the one to whom everything in the world refers," the researchers found seven factors: Creator, Love, Judge, Relationship with God (i.e., God's engagement in the world) and more abstract dimensions including Positive Power, Nature, and Difficult to Describe.

Despite these attempts to assess both personified and abstract God representations, there have been problems with reliability, small sample sizes, and interpretability in various studies. Moreover, measures of 53 to 91 items are often simply too long for current research. Recently, researchers have extracted a few salient words from existing measures for their own research (Exline et al., 2015; Tsang \& McCullough, 2005; Wong-McDonald \& Gorsuch, 2004). Others have created their own short list of adjectives (Flannelly, Koenig, Galek, \& Ellison, 2007; Francis, Gibson, \& Robbins, 2001; Nguyen \& Zuckerman, 2016; Shariff \& Norenzayan, 2011). In an effort to create a relatively brief measure with good psychometric properties, Johnson et al. (2015) developed a two-dimensional, 18-item measure of personal God representations: Authoritarian and Benevolent (the A/B Scale). The Authoritarian dimension generally corresponds with the dimensions of Wrath (Gorsuch, 1968), Judge (Hutsebaut \& Verhoeven, 1995), Controlling God (Benson \& Spilka, 1973) and Punitive/Anthropomorphic 
(Kunkel et al., 1999) factors in previous work. The Benevolent dimension corresponds with Traditional Christian (Gorsuch, 1968), Love (Hutsebaut \& Verhoeven, 1995), Loving God (Benson \& Spilka, 1973) and Nurturant/Anthropomorphic (Kunkel et al., 1999). Notably, Johnson et al.'s measure differed from previous measures in that the descriptors of Authoritarian God were chosen to reflect belief in a moralizing God rather than a cruel, damning God.

Yet the A/B Scale did not include any of the abstract factors that had emerged in earlier work such as (a) Omni/Positive Power (Gorsuch, 1968; Hutsebaut \& Verhoeven, 1995), (b) Mystical/God in Nature (Hutsebaut \& Verhoeven, 1995; Kunkel, et al., 1999), or (c)

Deistic/Difficult to Describe (Gorsuch, 1968; Hutsebaut \& Verhoeven, 1995). It is important to address this gap because, as previously discussed, many people have a view of God as being a transcendent power, as indescribable, or more like a cosmic force.

\section{Assessing abstract God representations}

Drawing upon the previous research described above, as well as spirituality websites, our own pilot studies using exploratory factor analyses, open-ended survey questions, and undergraduate focus groups, we found evidence for three distinct dimensions related to abstract representations of God: Limitless emphasizing the vastness of God; Mystical emphasizing views of God as nature or as a mystical, cosmic force; and Ineffable emphasizing one's inability to comprehend or articulate who or what God is. Preliminary items for each dimension of abstract God representations are discussed below. We planned to add items assessing these three dimensions to Johnson et al.'s (2015) A/B God scale in order to provide a brief, easy-toadminister measure of both anthropomorphic and abstract God representations.

Limitless. We wanted to avoid using typically religious terms such as omnipresent, omnipotent, or eternal, which we expected would have a strong positive response bias for theists 
and little discriminant validity. Therefore, we chose related but more generally descriptive adjectives to capture the notion of an omnipresent spirit who many might claim abides even in the farthest reaches of the heavens: Supreme, Absolute, Vast, Limitless, and Infinite. A thesaurus search suggested additional adjectives: Transcendent, Boundless, and Immense.

Mystical. One group of individuals who are likely to hold abstract views of God are those who identify as Spiritual but not Religious (SBNR) or New Age. New Age often involves a belief in the universe as being permeated with a divine energy or an effort to attain 'higher levels' of consciousness and personal growth (Flere \& Kirbis, 2009). In his descriptions of religious experience, James (1902/2002) noted that people may also experience God in nature. Adjectives that were selected to resonate with SBNR and New Age individuals and indicators of a mystical God were: Mystical, Nature, Energy, Universe, Cosmic, and Consciousness.

Ineffable. Alternatively, many people may be unclear about who or what God is. The absence of a clear God representation may be due to a lack of care or attention, but may also reflect a philosophical belief that God is beyond anything that can be imagined or known (Silverman et al., 2016). The inability to describe the Divine has been referred to as Ineffable (James, 1902/2002) and descriptors of an Unknowable or Incomprehensible God might also include Inconceivable, Unimaginable, or Unknown. A God who cannot be adequately described or known may also be thought of as Silent, Distant, or Absent.

\section{Overview of studies}

Our goal in the present research was to develop a relatively short measure of God representations which could account for various personified and abstract views of God relevant for agnostics, monotheists, deists, pantheists, and panentheists alike. We refer to our new measure as the LAMBI scale. 
In Study 1, we examined the factor structure of the descriptors described above representing what we believed could reliably assess at least five different dimensions of God representations: Limitless (L), Authoritarian (A), Mystical (M) Benevolent (B), and Ineffable (I). In Study 2, we submitted a subset of the original items to confirmatory factor analysis and provide an initial validation of the scale using both existing and new measures of religiosity. In Study 3, we examined the test-retest reliability of the five scales. In Study 4, we sought to demonstrate the incremental validity of the new 25-item LAMBI scale by examining the ability of the five LAMBI subscales to predict political conservatism, certain values and afterlife beliefs above and beyond two extant measures of God concepts/ images. In Study 5, we conducted a latent profile analysis to investigate response patterns across the five subscales.

\section{Study 1: Exploratory Factor Analysis}

The goal of Study 1 was to carry out an exploratory factor analysis of our initial list of 41 items (Table 1), in order to discard poor-fitting items. We expected to find a five factor structure.

\section{Method}

Participants. Participants were recruited from the Mechanical Turk website and were paid \$1 each for completing a survey regarding beliefs about God. Participants were first prescreened for belief that God exists. Participants who rated their belief in God as 2 or more on a 5-point scale (anchor points: $1=$ God certainly does NOT exist, and $5=$ God certainly DOES exist) were directed to the study site. There were 288 qualified participants (156 females). Most (71.2\%) were Euro-American. The sample consisted of 157 non-Catholic Christians, 66 Catholics, 39 Spiritual but not Religious, 12 Jews, 6 Muslims, 4 Agnostics, 4 'other'. The average age of participants was $34.89(S D=12.14)$. All of the studies here were conducted under the same exempt IRB protocol (\#00001445). 


\section{Measures.}

God Representations. Following Johnson et al. (2015) and Zahl \& Gibson (2012), participants were given the following instructions: "There are many ways of thinking about God, but some of God's traits seem more relevant to us than others. Using a wide range of the scale below, please rate how well each word describes God, a Higher Power, or Divine Life ForceBASED UPON YOUR OWN, PERSONAL EXPERIENCE AND BELIEFS (as opposed to what you 'should' believe or what is theologically or philosophically correct)."

Participants were asked to provide Likert-scale ratings from $1=$ strongly disagree to $7=$ strongly agree regarding the following items: strict, punishing, wrathful, judging, stern, angry, restricting, controlling, commanding (Authoritarian); forgiving, caring, merciful, accepting, compassionate, helping, gracious, tolerant, generous (Benevolent); boundless, vast, infinite, immense, limitless, transcendent, absolute, and supreme (Limitless); nature, the universe, energy, consciousness, cosmic, mystical, Om (Mystical); unimaginable, unknowable, unknown, incomprehensible, inconceivable, distant, silent, absent (Ineffable).

Participants also provided ratings of God as a personal being, cosmic force, or no view of God using a multiple choice item from the General Social Survey (Godview variable; Smith, 2011). The results are provided in the Online Supplemental material. Finally, participants completed measures of Self/God overlap (Hodges, Sharp, Gibson, \& Tipsord, 2012) and God's engagement in the world (Degelman \& Lynn, 1995). The results are not presented here but similar measures were used and reported in the analyses in Study 2.

\section{Results and Discussion}

We conducted an exploratory factor analysis using principal components analysis (PCA), with direct oblimin rotation and Kaiser normalization. An examination of eigenvalues and 
percentage of variance explained suggested a five-factor solution (Table 1). Supreme was the single item with high cross-loading (.40); so this item was omitted from the final set of 40 items.

\section{Study 2: Confirmatory Factor Analysis}

In Study 2, we conducted a confirmatory factor analysis of the LAMBI scale items. For pragmatic reasons, in Study 2, we also sought to shorten the number of items in the measure without compromising the reliability of each of the five subscales. Finally, in Study 2, we assessed several measures of religiosity in order to accrue evidence for construct validity. We expected the following correlations: (a) Authoritarian with religious fundamentalism; (b) Authoritarian, Benevolent, and Limitless with religious commitment, God's engagement in human affairs, and self/God overlap; (c) Mystical with individualistic spirituality; and (d) Ineffable with a Quest religious orientation (Batson \& Schoenrade, 1991).

\section{Method}

Participants. Participants were recruited via the Mechanical Turk website and first completed a prescreening survey as in Study 1. There were 341 qualified participants (191 females). Most (79.2\%) were Euro-American. Participants indicated their religious affiliation from a list: 144 non-Catholic Christians, 75 Agnostics, 64 Catholics, 41 Spiritual but not Religious, 7 Jews, 7 Atheists, 3 'other.' The average age of participants was $36.50(S D=11.37)$.

Measures. Participants completed the following measures as well as Biblical literalism and awareness of God measures which were highly correlated with other religious variables and, therefore, not reported here. Except for the Godview single item and the self/God overlap measure, all measures used a Likert scale of $1=$ strongly disagree to $7=$ strongly agree.

God representations. Participants reported the extent to which they agreed that each of the adjectives from Study 1 were descriptive of God, based upon their own personal experience 
and not what was theologically correct. However, because one goal of Study 2 was to reduce the number of items in the LAMBI scale, we omitted the item on each of the new subscales that had the lowest factor loading in Study 1, absolute, Om, and absent.

Correlates of God representations. We expected that personified views of God would reflect a traditional approach to religiosity in terms of religious commitment, fundamentalism, and belief that God is engaged in human affairs. We expected that belief in a benevolent God would be associated with closeness to God evidenced by higher scores on the Self/God overlap measure. We expected that limitless, mystical, and ineffable representations would be endorsed by those with individualistic or quest approaches to religion and spirituality.

Godview. Participants were asked to rate the extent to which they agree with three single items adapted from the Godview variable in the General Social Survey (Smith, 2011): “God is a personal being involved in human affairs," "God is a not a person but is something more like a cosmic or transcendent life force," or "I have no clear view of who or what God is."

Religious Fundamentalism. We assessed religious fundamentalism using the 12 -item Religious Fundamentalism scale (Altemeyer \& Hunsberger, 1992) $(\alpha=.95)$.

Religious commitment. We assessed religiousness with the Religious Commitment Inventory (RCI; Worthington et al., 2003). The measure consists of 10 items assessing both personal religiousness (e.g., spending time in prayer) and commitment to one's religious group (e.g., participating in, donating to, and keeping informed about the religious group) $(\alpha=.95)$.

God's engagement in human affairs. We assessed God's engagement in human affairs using a 7-item scale (Degelman \& Lynn, 1995) $(\alpha=.94)$.

Self/God overlap. We assessed self/God overlap using a diagram with two circles overlapping to various degrees similar to the measure developed by Aron, Aron, and Smollan 
(1992). The circles in the Self/God overlap diagram are labeled Self and God and participants are asked to indicate which pair of overlapping circles best represents the participant's relationship with God (Hodges et al., 2012; Sharp et al., 2017).

Individualistic spirituality. Although there are extant measures of spirituality, we were unaware of a measure of individualistic spirituality, so we created a measure with five statements, "My spirituality often leads me to develop novel, inspired, creative beliefs of my own," "My religious and spiritual beliefs are based upon my own understanding gleaned from multiple faith traditions," "I have my own religious or spiritual beliefs that are not quite like anyone else's," "Every individual must seek out and find his or her own spiritual truth," and "Spirituality is unique to every individual" $(\alpha=.81)$.

Quest religious orientation. We assessed religious doubts and religious seeking using the 12-item Quest religious orientation scale (Batson \& Schoenrade, 1991) $(\alpha=.85)$.

\section{Results and Discussion}

Our data analytic plan was to (a) identify the five highest loading items on each of the five subscales in order to reduce the number of items in the LAMBI scale to 25, (b) conduct a confirmatory factor analysis on the shorter, 25-item measure, and (c) provide an initial validation of the five 5-item subscales using general measures of religion and spirituality.

Reducing the scale length. We first conducted a Principal Components Analysis of the of the God representation items in order to identify the five highest loading items for each subscale. Two items, silent and distant, cross-loaded and had factor scores less than .40. Therefore, we omitted these two items and ran the analysis a second time. The factor loadings for the remaining 35 items are shown in the first column in Table 1.

\footnotetext{
**Table 1 about here**
} 
Confirmatory factor analysis. We used Mplus version 7.4 (Muthen \& Muthen, 19982015) to perform a CFA using the five highest loading items for each of the five subscales_-but with two exceptions. First, Johnson et al. (2015) intended the Authoritarian God subscale to assess representations of God as moralizing and not merely vengeful. Therefore, we retained Commanding and omitted the higher loading, but perhaps more negatively-valenced items, Controlling and Judging. Second, in selecting the five Benevolent items, we omitted several similar, higher loading items: Caring, Accepting, Generous, and Helping. We retained the lower loading item, Tolerant, as being in contrast with the Authoritarian item, Commanding.

In the model, all 25 indicators were specified to load on only one subscale (i.e., one of the five latent variables: Authoritarian, Benevolent, Limitless, Mystical, or Ineffable). The loadings for the items Commanding, Forgiving, Vast, Nature, and Unknowable were fixed at 1.0 on their respective subscales. The five subscales were allowed to correlate. The model provided a good fit for the data, MLR, $X^{2}(262)=427, \mathrm{RMSEA}=.043, \mathrm{CFI}=.961, \mathrm{SRMR}=.078$. Items and factor loadings for each subscale are shown in the first column of Table 1.

Correlates of the 5-factor scale. We computed the average scores, standard deviations, and correlates for each of the five subscales using the final 25 items. The correlations between the five LAMBI dimensions and the religion/spirituality variables are provided in Table 2.

$* *$ Table 2 about here**

\section{Study 3: Test-Retest Reliability of the Five Factor LAMBI Scale}

God Representations are subject to changes in social context (Johnson et al., 2013; Wilt, Exline, Lindberg, Park, \& Pargament, 2017) as well as over a lifetime (Rizzuto, 1979). However, we expected the LAMBI scale to have good test-retest reliability across short periods of time.

\section{Participants and Procedure}


Participants were 98 MTurk workers who had participated in a larger study at Time 1. We used the TurkPrime interface (Litman, Robinson, \& Abberbock, 2016) to recruit these same participants five days later at Time 2. All participants had been notified at Time 1 that they may qualify for a second study and that their worker ID would be used to match the data from Times 1 and 2 if they participated in both studies (IRB Protocol \#00006037).

There were 48 females. Most participants (76.5\%) were Euro-American. Participants indicated their religious affiliation from a list at Time 1: 25 non-Catholic Christians, 11 Catholics, 28 Spiritual but not Religious, 17 Atheists, 12 Agnostics, 3 Muslims, and 2 Buddhists. The average age of participants was $37.50(S D=12.17)$.

\section{Results and Discussion}

The means and standard deviations for the two time points, for each of the subscales, are provided in the Online Supplemental material. The correlations of Time 1 and Time 2 were significant for all subscales: Authoritarian, $r=.85$, Benevolent, $r=.94$, Limitless, $r=.92$, Mystical, $r=.85$, and Ineffable, $r=.75$. Paired samples $t$-tests examining changes in scores indicated that all five subscales also exhibit stability in their group means and there were no significant changes. Thus, the LAMBI scale has good stability and test-retest reliability.

\section{Study 4: Incremental Validity of the LAMBI Scale}

In Study 4, we investigated the ability of the five dimensions of the LAMBI scale to predict beliefs and values over and above two other measures of God representations. Researchers have generally distinguished between God concepts and God images (Davis, et al., 2013) whereas concepts are thought to be grounded in doctrinal, propositional, cold cognition, images are thought to be grounded in experiential, implicational, hot (affective) cognition (Hall \& Fujikawa, 2013; Zahl \& Gibson, 2012). In Study 4, we compared the LAMBI scale to both 
Benson and Spilka’s (1973) God concept and Lawrence's (1997) God image scales. As

previously discussed, the Benson and Spilka God concept scale consists of two subscales assessing Christians' belief in a controlling and a loving God. Lawrence's God image measure was intended to assess three aspects of Christians' feelings and lifetime experiences with God: God's control, God's goodness, and feelings of belonging to God.

To investigate the ability of the LAMBI scale to predict certain beliefs and values over and above the God concept and God image scales, we asked participants to complete measures of political conservatism, the values of benevolence, universalism, affinity with nature, and belief in reincarnation, as part of a larger survey.

We expected the new LAMBI-Authoritarian subscale to be positively correlated with both the Controlling God concept and God image. In contrast, we expected the LAMBIBenevolent subscale to be positively correlated with the Loving God concept and the Goodness of God image. We expected an authoritarian God representation to be a positive predictor of political conservatism and a benevolent God representation to be positively linked with the value of benevolence after controlling for the extant God concept and God image measures.

However, the Limitless, Mystical, and Ineffable dimensions were designed to assess relatively more abstract views of God. We reasoned that having an abstract representation of God as being infinite and boundless (i.e., Limitless) would correspond with an expanded sense of "we." We expected representations of God as Limitless to be positively associated with the value of universalism after controlling for the extant God concept and God image scales.

Author (in press) has shown that high scores on the Mystical dimension (e.g. God as nature, energy, cosmic, the universe) are positively associated with the value of nature. Thus, we expected the Mystical dimension to be a positive predictor of affinity for nature after controlling 
for the extant God concept and God image scales. Abstract representations of God may be associated with a wide range of non-traditional Christian beliefs (e.g., reincarnation, astrology, evil eye) culled from diverse religious traditions (Pew Forum on Religion \& Public Life, 2009). We expected both Mystical and Ineffable God representations to be associated with belief in Reincarnation after controlling for the extant God concept and God image scales.

\section{Method}

Participants. Participants living in the U.S. were recruited via the Mechanical Turk website and completed a prescreening question as in Studies 1 and 2. To qualify, participants must have reported a belief in God score of 2 or more on a scale of 1 to 5 . There were 284 qualified participants (160 females). Most (75.4\%) were Euro-American. Participants were 103 non-Catholic Christians, 51 Catholics, 75 Atheists/Agnostics, 40 Spiritual but not Religious, 6 Buddhist, 5 Jews, and 4 Muslims. The average age of participants was $37.66(S D=12.57)$.

Measures. Items were rated on a $1=$ strongly disagree to $7=$ strongly agree Likert scale.

LAMBI scale. Participants completed the 25-item LAMBI scale: Authoritarian $(\alpha=.90)$, Benevolent $(\alpha=.95)$, Limitless $(\alpha=.86)$, Mystical $(\alpha=.95)$, and Ineffable $(\alpha=.88)$.

God concepts. The Controlling God $(\alpha=.86)$ and Loving God $(\alpha=.95)$ scales (Benson \& Spilka, 1973) consist of ten sets of adjectives scored on a 7-point sematic differential scale. Five adjective pairs assess the concept of a controlling God and five pairs assess the concept of a loving God. Participants are asked to rate the extent to which they agree that God is, for example, Restricting versus Freeing (Controlling God) or Damning versus Saving (Loving God).

God images. The God Image Scale (Lawrence, 1997) is a 72-item measure designed to assess relating to God in terms of God's Control ( $\alpha=.95$; Influence and Providence), God's Goodness $(\alpha=.93$; Benevolence and Acceptance), and Belonging ( $\alpha=.96$; Presence and 
Challenge). Sample items are: "When I obey God's rules, God makes good things happen for me" (Control); "I think of God as more compassionate than demanding" (Goodness); and "I sometimes feel cradled in God's arms" (Belonging).

Political Conservatism. We assessed political conservatism with a single item, "How would you describe your political leanings?" rated from $1=$ very liberal to $5=$ very conservative.

Values. In the Schwartz Values Instrument (Schwartz, 1992; Schwartz, et al., 2012), participants are asked to rate the extent to which they agree that each of 57 statements describes values which are "a guiding principle of your life." The statements from 19 classes of values including Benevolence (Caring and Dependable; $\alpha=.81$ ), Universalism (Tolerance and Social Justice; $\alpha=.83)$, and Affinity for Nature $(\alpha=.82)$ which were of primary interest here.

Belief in Reincarnation. We assessed belief in reincarnation using three new items: "Reincarnation is real," "After death, people will return to this world as another person or in a different form," and "I believe in a reincarnated afterlife" $(\alpha=.95)$.

\section{Results}

God representation measures. The Authoritarian subscale was most strongly correlated with the Controlling God concept, $r(284)=.44$. The Benevolent subscale was positively correlated with the other God concept and God image scales ( $r$ s range from .65 to .83 ) except for the Controlling God concept scale, $r(284)=-.55$. Similar associations were observed for the Limitless and Mystical subscales. For the Limitless subscale, the positive correlations with the God concept and God image scales ranged from .42 to .63 and the negative correlation with the Controlling God concept was $r(284)=-.35$. For the Mystical subscale, the positive correlations with the God concept and God image scales ranged from .23 to .42 and the negative correlation with the Controlling God concept was $r(284)=-.32$. 
Incremental validity. To establish the incremental validity of the LAMBI subscales, we carried out the five hierarchical multiple regression analyses shown in Table 3. We regressed Conservatism, the values of Benevolence, Universalism, Nature, and Belief in Reincarnation on the God concept scales (Controlling God and Loving God) at Step 1, the God image scales (Control, Goodness, and Belonging) at Step 2, and the LAMBI scales (Authoritarian, Benevolent, Limitless, Mystical, and Ineffable) at Step 3.

**Table 3 about here**

Political Conservatism. LAMBI-Authoritarian was a significant and positive predictor of political Conservatism after controlling for both God concept and God image. Mystical was a significant negative predictor suggesting that Mystical may be more likely to be endorsed by liberals. Overall, the LAMBI scale contributed significantly to the model with an increase in the variance explained of $5 \%$, partial $F(5,273)=3.46, p=.005$.

Benevolence. Although LAMBI-Benevolent was positively correlated with the value of Benevolence, $r(284)=.44, p<.001$, LAMBI-Benevolent was not a significant predictor of Benevolence in the regression model $(p=.092)$ after controlling for extant God concept and God image scales. This is understandable inasmuch as the God concept and God image scales were designed to assess positive beliefs about and experiences with God much like the LAMBIBenevolent subscale. Overall, the LAMBI scale contributed only an additional $2 \%$ of the variance explained, partial $F(5,273)=1.24, p=.288$.

Universalism. Although LAMBI-Limitless was positively correlated with the value of Universalism, $r(284)=.17, p=.005$, in the final regression model, Limitless was a negative and non-significant predictor of Universalism. Mystical was the only positive predictor after controlling for God concept and God image. Notably, LAMBI-Ineffable was also a significant 
negative predictor of Universalism. Overall, the LAMBI scale contributed significantly to the model with an increase in the variance explained of $8 \%$, partial $F(10,273)=5.07, p<.001$.

Nature. LAMBI-Mystical was a significant positive predictor of Affinity with Nature. Although Limitless was positively correlated with Affinity with Nature, $r(284)=.12, p=.036$, LAMBI-Limitless was a significant negative predictor in the model after controlling for God concept and God image. LAMBI-Authoritarian was also a significant negative predictor of Affinity with Nature. Overall, the LAMBI scale contributed significantly to the model with an increase in the variance explained of $14 \%$, partial $F(5,273)=9.30, p<.001$.

Belief in reincarnation. LAMBI-Ineffable was a significant positive predictor of Belief in Reincarnation after controlling for God concept and God image. In addition, Mystical was a positive predictor. Although bivariate correlations revealed that LAMBI-Limitless was positively correlated with Belief in Reincarnation, $r(284)=.14, p=.018$, Limitless was a significant negative predictor in the regression model. Overall, the LAMBI scale contributed significantly to the model with an increase in the variance explained of $10 \%$, partial $F(5,273)=7.03, p<.001$.

\section{Discussion}

The LAMBI scale is related to, but also differs from, two extant God concept (Benson \& Spilka, 1973) and God image (Lawrence, 1997) measures. The LAMBI scales often predicted outcomes of interest controlling for existing God concept measures. One limitation of Study 4 is that the measure of belief in Reincarnation has not been validated in other studies. Nevertheless, we suggest that the results presented here demonstrate the incremental validity of the 25 -item LAMBI scale controlling for the 82 items of the God concept and God images scales. We believe the Mystical dimension — which was designed to assess spiritualist or naturalistic views of 
God-will be an important measure in future research. Moreover, the Ineffable dimension will be useful in investigating the beliefs and social attitudes of the ever-increasing non-religious.

\section{Study 5: Latent Class Analysis and Religious Group Differences}

Study 5 reports common response patterns across our multi-dimensional scale.

\section{Participants and Procedure}

There were 1,434 participants (809 females) in the U.S. recruited from Mechanical Turk. Participants were primarily Euro-American (75.9\%). Unlike the earlier studies, participants were pre-screened for religious affiliation rather than belief in God. Participants must have been nonCatholic Christian $(n=633)$, Agnostic $(n=358)$, Catholic $(n=261)$, Spiritual but not Religious $(n=135)$, Jewish $(n=30)$, or Muslim $(n=17)$. The average age was $35.87(S D=12.56)$.

Participants completed the LAMBI scale as part of a larger study of values and social attitudes with questionnaires similar to those assessed in Study 4. We had observed that Ineffable was negatively correlated with many religion variables in previous studies suggesting that Ineffable may be a measure of unbelief. Thus, we added a 3-item measure of unbelief (NoGod) for comparison: "God is imaginary," "God is not real," and "God is non-existent."

\section{Results and Discussion}

Descriptive Statistics. We first computed the scores for each of the God representations and unbelief: Authoritarian $(\alpha=.90, M=3.55, S D=1.61)$; Benevolent $(\alpha=.94, M=5.32, S D=$ 1.57); Limitless $(\alpha=.92, M=5.66, S D=1.37)$; Mystical $(\alpha=.83, M=5.12, S D=1.34)$; Ineffable $(\alpha=.86, M=4.06, S D=1.67)$; and NoGod (i.e., $\alpha=.92, M=2.72, S D=1.67)$.

Latent Profile Analysis. We used mixture modeling (latent profile analysis; LPA) to examine the response patterns across the five subscales and unbelief. LPA is similar to factor analysis and assumes there is one latent profile or group of similar responses, $k$. A subsequent 
model is specified with $k+1$ groups and fit statistics are provided to compare the two models for best fit. The steps are repeated until the optimal number of latent profile groups emerges. We provide the LPA statistical results in Table 5 in the Online Supplemental material.

** Figure 1 about here**

The best fitting model yielded four profile groups. Figure 1 shows the prototypical mean scores for each of the God representations, by latent profile group. Class $1(n=59$, Unbelief $)$ is characterized by high scores on NoGod. Class $2(n=85$, Abstract $)$ is characterized by high scores for Limitless, Mystical, and Ineffable. Class 3 ( $n=904$, Relational $)$ is characterized by high scores for Benevolent, Limitless, and Mystical but low scores for NoGod. Class 4 ( $n=386$, Amorphous) is characterized by the lack of variability across the six subscales. The emergence of the Amorphous class was unanticipated but may reflect an undifferentiated concept of God.

LPA class and religious group. An LPA class probability can be assigned to each participant, and we examined the relationship between LPA Class and four religious groups: Agnostic, Christian (Catholic and Non-Catholic Christian), Muslim/Jew (non-Christian monotheists), and SBNR. We predicted that: (a) the percentage of participants classified as Unbelief would be highest among Agnostics, (b) the percentage of participants classified as Abstract would be highest among Muslims/Jews, and SBNRs, and (c) the percentage of participants classified as Relational would be highest among Christians. Contrary to our expectations, the Chi square test was not significant, $X^{2}(9)=14.65, p=.101$, suggesting that there is no significant relation between religious affiliation and LPA class.

\section{GENERAL DISCUSSION}

In the present research, we developed and demonstrated the incremental validity of a measure to systematically assess both personified and abstract representations of God. Using 
EFA (Study 1) and CFA (Study 2), we selected a list of 25 commonly used adjectives which participants rate as descriptive of God, a Higher Power, or Divine Life Force. We refer to this relatively short, multidimensional measure as the LAMBI scale, an acronym for Limitless, Authoritarian, Mystical, Benevolent, and Ineffable. Each of the five subscales was differentially associated with diverse measures of religion and spirituality, values, and political conservatism.

Representations of God as Authoritarian (punishing, wrathful, strict, stern, and commanding) were associated with fundamentalism, religious commitment, a view of God as a personal being, and political conservatism. This is consistent with previous research (e.g., Froese \& Bader, 2010; Johnson et al., 2015). We found that belief in a punishing, moralizing (i.e., Authoritarian) God had relatively low scores compared with the other dimensions in thinking about God. It appears that in today's society—at least in the U.S.- - belief in the benevolent, limitless, and mystical attributes of God are more likely to be predominant.

There has been some research distinguishing between representations of God as authoritarian and benevolent (e.g., Benson \& Spilka, 1973; Froese \& Bader, 2010; Johnson et al., 2013; Johnson et al., 2015; Shariff \& Norenzayan, 2011; Zwingmann \& Gottschling, 2015). Although the Benevolent and Authoritarian dimensions were similarly associated with views of God as a personal being and with religious commitments, Benevolent (forgiving, compassionate, gracious, merciful, tolerant) was also positively associated with self/God overlap, whereas Authoritarian was not. It was striking that Benevolent God representations were also positively correlated with the values of universalism and affinity with nature whereas Authoritarian representations were either uncorrelated or negatively correlated with these same values.

The correlates of the Limitless dimension were very similar to those of the Benevolent dimension with a few exceptions. Notably, and as predicted, Limitless God representations 
(limitless, vast, immense, infinite, boundless) were positively associated with views of God as a personal being but also as a cosmic force. Additionally, Limitless was positively correlated with individualistic spirituality, an appreciation for religious diversity.

The Mystical dimension (nature, energy, cosmic, consciousness, the universe) was closely linked with views of God as a cosmic force. Surprisingly, however, Mystical was also associated with religious commitment, a belief in God's engagement in human affairs, and self/God overlap — albeit the magnitude of the correlations were small relative to the Benevolent and Limitless dimensions. Mystical was also associated with individualistic spirituality, Quest orientation, and belief in reincarnation. In terms of values, Mystical was associated with the values of benevolence, universalism, affinity with nature. What was most striking is that, even after controlling for God concepts, God images, and the other four dimensions of the LAMBI scale, the Mystical dimension was the strongest predictor of these values. Thus, the Mystical dimension seems to provide a missing piece in our understanding of how individuals in the U.S. represent God and how those representations might be related to other beliefs and values.

All the participants in the five studies had expressed some degree of belief in God. We had originally conceptualized Ineffable (inconceivable, incomprehensible, unimaginable, unknowable, and unknown) as indicating that God was too great to imagine and we expected this abstract representation to be especially relevant for Jews and Muslims (Silverman et al., 2016). However, when examining the measurement models and correlates, we realized that Ineffable may be better conceptualized as a measure of uncertainty about the nature and attributes of God.

\section{Limitations and Future Directions}

There are various frameworks for classifying God representations. For example, Wilt, et al. (2017) theorize that there are three levels of God concepts reflecting ways of relating to the 
divine: Global concepts giving a general impression of God's attributes, Mid-level concepts grounded in one's overall experiences with God, and Context-specific concepts. More research is needed to classify the various dimensions of the LAMBI scale within this framework. We note, however, that Wilt et. al's trilevel framework may be most appropriate for relating to God as a personal being but less useful in understanding impersonal representations of God.

We are also agnostic regarding the extent to which people draw upon docrtinal concepts versus experiential images when responding to the items on the LAMBI scale. Although the LAMBI scale instructs participants to describe the attributes of God based upon their own personal experiences and not what is theologically accurate, we expect that people will typically draw, in parallel fashion, on both doctrinal and experiential knowledge when asked about the attributes of God. Accordingly, in the present research, we refer to the dimensions of the LAMBI scale as God representations rather than God concepts or God images. However, more research is needed to better understand whether God concepts or God images are being assessed.

We are also quick to acknowledge that no list of adjectives could fully capture everything that has been imagined, spoken, or written about the Divine. Further, although we believe at least one or more of the five dimensions in the LAMBI scale will resonate well with Agnostics, SBNRs, and monotheists in the Abrahamic traditions, more research is needed to assess whether the dimensions of the LAMBI scale are relevant for individuals in other religious (e.g., Hindu), spiritual (e.g., Native American Traditionalist), or philosophical (e.g., Buddhist) groups. Along those same lines, the scale may be less useful in research with Atheists who are likely to disagree or provide neutral responses on all 25 items.

This research is also limited in that we relied entirely on the Mechanical Turk population for our samples. However, we note that others have used nationally representative samples and 
found similar complexity in God representations (e.g., Froese \& Bader, 2010). Another limitation is that our measures of individualistic spirituality and belief in reincarnation were also new. Although the reliability and face validity of the items in both measures seemed good, these two measures which were used to validate the LAMBI scale have not been published elsewhere.

\section{Conclusion}

We believe there is a need for this brief, psychometrically sound, multidimensional measure assessing both personal and abstract God representations as these might have implications for both theory and religious priming, and researchers may want to consider the potential mediating and moderating effects of specific beliefs about God, rather than simple belief or disbelief, or belief in one kind of God (e.g. a moralizing high god).

In sum, the LAMBI scale reveals important individual differences in thinking about God and the results presented here constitute an important next step in understanding how very basic beliefs about God may also be associated with individual differences in religiosity, spirituality, values, and —ultimately—ways of relating with both humans and the Divine. 


\section{References}

Altemeyer, B., \& Hunsberger, B. (1992). Authoritarianism, religious fundamentalism, quest, and prejudice. The International Journal for the Psychology of Religion, 2, 113-133.

Aron, A., Aron, E. N., \& Smollan, D. (1992). Inclusion of other in the self scale and the structure of interpersonal closeness. Journal of Personality and Social Psychology, 63 , 596-612.

Barbour, I. G. (1998). Religion and Science: Historical and Contemporary Issues. London: SCM Press Ltd.

Batson, C. D., \& Schoenrade, P. (1991). Measuring religion as quest: Reliability concerns. Journal for the Scientific Study of Religion, 30, 430-447.

Benson, P., \& Spilka, B. (1973). God image as a function of self-esteem and locus of control. Journal for the Scientific Study of Religion, 12, 297-310.

Bishop, G. (1999). The polls - trends: Americans' belief in God. Public Opinion Quarterly, 63, 421-434.

Buber, M. (1986/1958). I and Thou. (R. G. Smith, Trans.) New York: Scribner Classics.

Bushman, B. J., Ridge, R. D., Das, E., Key, C. W., \& Busath, G. L. (2007). When God sanctions killing: Effect of scriptural violence on aggression. Psychological Science, 18, 204-207.

Cheston, S. E., Piedmont, R. L., Eanes, B., \& Lavin, L. P. (2003). Changes in clients' images of God over the course of outpatient therapy. Couneling and Values, 47, 96-108.

Davis, E. B., Moriarty, G. L., \& Mauch, J. C. (2013). God images and God concepts: Definitions, development, and dynamics. Psychology of Religion and Spirituality, 5, 51 60.

Degelman, D., \& Lynn, D. (1995). The development and preliminary validation of the Belief in Divine Intervention Scale. Journal of Psychology and Theology, 23, 37-44. 
Exline, J. J., Grubbs, J. B., \& Homolka, S. J. (2015). Seeing God as cruel or distant: Links with divine struggles involving anger, doubt, and fear of God's disapproval. The International Journal for the Psychology of Religion, 25, 29-41.

Fiala, W. E., Bjorck, J. P., \& Gorsuch, R. (2002). The religious support scale: Construction, validation, and cross-validation. American Journal of Community Psychology, 30, 761786.

Flannelly, K. J., Koenig, H. G., Galek, K., \& Ellison, C. G. (2007). Beliefs, mental health, and evolutionary threat assessment systems in the brain. Journal of Nervous and Mental Disease, 195, 996-1003.

Flere, S., \& Kirbis, A. (2009). New Age, religiosity, and traditionalism: A cross-cultural comparison: Comment on Houtman and Aupers, JSSR, September 2007. Journal for the Scientific Study of Religion, 48, 161-169.

Francis, L. J., Gibson, H. M., \& Robbins, M. (2001). God images and self-worth among adolescents in Scotland. Mental Health, Religion \& Culture, 4, 103-108.

Froese, P., \& Bader, C. (2010). America's four Gods: What we say about God - \& what that says about us. Oxford: Oxford University Press.

Gorsuch, R. L. (1968). The conceptualization of God as seen in adjective ratings. Journal for the Scientific Study of Religion, 7, 56-64.

Granqvist, P., Mikulincer, M., \& Shaver, P. R. (2010). Religion as attachment: Normative processes and individual differences. Personality and Social Psychology Review, 14(1), 49-59. 
Hall, T. W., \& Fujikawa, A. M. (2013). God image and the sacred. In K. I. Pargament, J. J.

Exline, \& J. W. Jones (Eds.), APA handbook of psychology, religion, and spirituality (Vol 1): Context, theory, and research (pp. 277-292). Washington, DC.

Hill, P. C., \& Hood, Jr., R. W. (Eds.). (1999). Measures of religiosity. Birmingham, AL: Religious Education Press.

Hodges, S. D., Sharp, C. A., Gibson, N. J., \& Tipsord, J. M. (2012). Nearer by God to Thee: Self-God overlap and believers' relationships with God. Self and Identity, 1-20.

Hutsebaut, D., \& Verhoeven, D. (1995). Studying dimensions of God representation: Choosing closed or open-ended research questions. The International Journal for the Psychology of Religion, 5, 49-60.

James, W. (1902/2002). The varieties of religious experience: A study in human nature. New York: The Modern Library.

Johnson, K. A., Li, Y. J., Cohen, A. B., \& Okun, M. A. (2013). Friends in high places: The influence of authoritarian and benevolent God-concepts on social attitudes and behaviors. Psychology of Religion and Spirituality, 5, 15-22.

Johnson, K. A., Okun, M. A., \& Cohen, A. B. (2015). The mind of the Lord: Measuring authoritarian and benevolent and God representations. Psychology of Religion and Spirituality, 7, 227-238.

Krejci, M. J. (1998). Gender comparison of God schemas: A multidimensional scaling analysis. The International Journal for the Psychology of Religion, 8, 57-66.

Kunkel, M. A., Cook, S., Meshel, D. S., Daughtry, D., \& Hauenstein, A. (1999). God images: a concept map. Journal for the Scientific Study of Religion, 38(2), 193-202. 
Lawrence, R. T. (1997). Measuring the image of God: The God image inventory and the God image scales. Journal of Psychology and Theology, 25, 214-226.

Litman, L., Robinson, J., \& Abberbock, T. (2016). TurkPrime.com: A versatile crowdsourcing data acquisition platform for the behavioral sciences. Behavior Research Methods, 1-10.

McCallister, B. J. (1999). Nonverbal measure of God-concept (Bassett, Miller, Anstey, Crafts, Harmon, Lee, Parks, Robinson, Smid, Sterner, Stevens, Wheeler, \& Stevenson, 1990)(Bassett, Perry, Repass, Silver, \& Welch, 1994). In P. C. Hill, \& J. Ralph W. Hood (Eds.), Measure of Religiosity (pp. 409-415). Birmingham, Alabama: Religious Education Press.

Muthen, L., \& Muthen, B. (1998-2015). Mplus User's Guide. Seventh Edition. Los Angeles, CA, Los Angeles, CA: Muthen \& Muthen.

Nadler, S. (2006). Spinoza's Ethics: An introduction. Cambridge: Cambridge University Press.

Nguyen, T.-v. T., \& Zuckerman, M. (2016). The links of God images to women's religiosity and coping with depression: A socialization explanation of gender difference in religiosity. Psychology of Religion and Spirituality, 8, 309-317.

Pew Forum on Religion \& Public Life. (2009). Many Americans mix multiple faiths: Eastern, New Age beliefs widespread. Retrieved October 18 2010, from Pew Forum: http://pewforum.org/Other-Beliefs-and-Practices/Many-Americans-Mix-MultipleFaiths.aspx\#1

Rizzuto, A. M. (1979). The birth of the living God: A psychoanalytic study. Chicago: University of Chicago Press.

Roberts, C. W. (1989). Imagining God: Who is created in whose image? Review of Religious Research, 30, 375-386. 
Schaefer, C., \& Gorsuch, R. L. (1992). Dimensionality of religion: Belief and motivation as predictors of behavior. Journal of Psychology and Christianity, 11, 244-254.

Schwartz, S. H. (1992). Universals in the content and structure of values: Theory and empirical tests in 20 countries. In M. Zanna (Ed.), Advances in experimental social psychology, Vol. 25 (pp. 1-65). San Diego, CA: US:Academic Press.

Schwartz, S. H., Cieciuch, J., Vecchione, M., Davidov, E., Fischer, R., \& al., e. (2012). Refining the Theory of Basic Individual Values. Journal of Personality and Social Psychology, 103, 663-688.

Shariff, A. F., \& Norenzayan, A. (2011). Mean gods make good people: Different views of God predict cheating behavior. The International Journal for the Psychology of Religion, 21, 85-96.

Sharp, C. A., Rentfrow, P. J., \& Gibson, N. J. (2017). One God but three concepts: Complexity in Christians' representations for God. Psychology of Religion and Spirituality, 9, 95-105.

Silverman, G., Johnson, K., \& Cohen, A. (2016). To believe or not to believe, that is not the question: the complexity of Jewish beliefs about God. Psychology of Religion and Spirituality, 8, 119-130.

Smith, T. M. (2011). General social survey, 1972-2010 cumulative file (ICPSR31521-v1) [data file and codebook]. Chicago: National Opinion Research Center [producer]. Ann Arbor, MI: Inter-university Consortium for Political and Social Research [distributor]. doi: 10.3886/ICPSR31521.v1.

Spilka, B., Armatas, P., \& Nussbaum, J. (1964). The concept of God: A factor-analytic approach. Review of Religious Research, 6, 28-36. 
Stark, R. (2007). Discovering God: The origins of the great religions and the evolution of belief. New York: Harper One.

Templeton, J. M., \& Herrmann, R. L. (1989). The God who would be known: Revelations of the divine in contemporary science. Philadelphia: Templeton Foundation Press.

Tsang, J.-A., \& McCullough, M. E. (2005). Psychometric and rationalization accounts of the religion-forgiveness discrepancy. Journal of Social Issues, 61, 785-805.

Vercruysse, G. (1972). The meaning of God: A factoranalytic study. Social Compass, 19, 347.

Vergote, A., Tamayo, A., Pasquali, L., Bonami, M., Pattyn, M., \& Custers, A. (1969). A concept of God and parental images. Journal for the Scientific Study of Religion, 8, 79-83.

Wilt, J. A., Exline, J. J., Lindberg, M. J., Park, C. L., \& Pargament, K. I. (2017). Theological beliefs about suffering and interactions with the divine. Psychology of Religion and Spirituality, 9, 137-147.

Wong-McDonald, A., \& Gorsuch, R. L. (2004). A multivariate theory of God concept, religious motivation, locus of control, coping, and spiritual well-being. Journal of Psychology and Theology, 32, 318-334.

Worthington, Jr., E. L., Wade, N. G., Hight, T. L., Ripley, J. S., McCullough, M. E., Berry, J. W., . . O'Connor, L. (2003). The Religious Commitment Inventory-10: Development, refinement, and validation of a brief scale for research and counseling. Journal of Counseling Psychology, 50, 84-96.

Zahl, B. P., \& Gibson, N. J. (2012). God representations, attachment to God, and satisfaction with life: A comparison of doctrinal and experiential representations of God in Christian young adults. The International Journal for the Psychology of Religion, 22, 216-230. 
Zwingmann, C., \& Gottschling, S. (2015). Religiosity, spirituality, and God concepts. Archive for the Psychology of Religion, 37, 98-116. 
Table 1. Standardized Factor Loadings for Confirmatory and Exploratory Factor Analyses of the God Representation Items

\begin{tabular}{|c|c|c|c|c|c|c|}
\hline Descriptor & $\begin{array}{l}\mathrm{CFA}^{-} \\
\text {Final } \\
\text { items } \\
\end{array}$ & $\begin{array}{l}\text { Factor } 1 \\
\text { Eigenvalue } \\
=12.06\end{array}$ & $\begin{array}{c}\text { Factor } 2 \\
\text { Eigenvalue } \\
=5.94\end{array}$ & $\begin{array}{c}\text { Factor } 3 \\
\text { Eigenvalue } \\
=4.04\end{array}$ & $\begin{array}{c}\text { Factor } 4 \\
\text { Eigenvalue } \\
\quad=1.92\end{array}$ & $\begin{array}{c}\text { Factor } 5 \\
\text { Eigenvalue } \\
=1.39\end{array}$ \\
\hline \multicolumn{7}{|l|}{ Benevolent } \\
\hline Forgiving & .92 & .90 & .05 & .03 & .06 & -.08 \\
\hline Merciful & .90 & .90 & .05 & .06 & .07 & -.06 \\
\hline Gracious & .91 & .88 & .11 & .00 & -.04 & -.02 \\
\hline Compassionate & .91 & .86 & -.06 & -.07 & -.02 & -.06 \\
\hline Tolerant & .79 & .82 & -.14 & .04 & -.19 & .06 \\
\hline Caring & -- & .88 & .05 & -.05 & -.04 & -.03 \\
\hline Accepting & -- & .87 & -.08 & .01 & -.13 & .02 \\
\hline Generous & -- & .85 & .03 & -.05 & -.01 & -.05 \\
\hline Helping & -- & .85 & .06 & -.07 & -.04 & -.04 \\
\hline \multicolumn{7}{|l|}{ Authoritarian } \\
\hline Punishing & .78 & -.04 & .88 & -.03 & -.04 & .06 \\
\hline Strict & .88 & .14 & .85 & .00 & .01 & .00 \\
\hline Wrathful & .71 & -.06 & .83 & -.05 & -.01 & .01 \\
\hline Stern & .88 & .09 & .83 & -.02 & -.05 & -.01 \\
\hline Commanding & .73 & .14 & .74 & -.13 & .06 & -.15 \\
\hline Controlling & -- & -.03 & .80 & -.01 & -.07 & .08 \\
\hline Judging & -- & .08 & .76 & .03 & .13 & -.12 \\
\hline Angry & -- & -.20 & .74 & .06 & .00 & .03 \\
\hline Restricting & -- & -.02 & .74 & .20 & -.04 & .08 \\
\hline \multicolumn{7}{|l|}{ Ineffable } \\
\hline Inconceivable & .86 & .07 & .04 & .90 & .02 & .00 \\
\hline Incomprehensible & .85 & .05 & .04 & .88 & .17 & -.14 \\
\hline Unimaginable & .83 & .09 & .00 & .88 & .03 & -.03 \\
\hline Unknowable & .66 & -.23 & .02 & .70 & -.09 & .08 \\
\hline Unknown & .58 & -.16 & -.05 & .67 & -.10 & .18 \\
\hline \multicolumn{7}{|l|}{ Mystical } \\
\hline Nature & .83 & .07 & -.01 & -.08 & -.84 & .00 \\
\hline Energy & .82 & .12 & .02 & -.05 & -.82 & .01 \\
\hline Universe & .80 & -.02 & .04 & -.07 & -.79 & -.11 \\
\hline Consciousness & .77 & .22 & -.01 & -.02 & -.70 & -.04 \\
\hline Cosmic & .60 & -.18 & .06 & .14 & -.48 & -.45 \\
\hline Mystical & -- & .05 & -.03 & .22 & -.43 & -.18 \\
\hline
\end{tabular}


Table 1. (continued)

\begin{tabular}{lcccccc}
\hline & $\begin{array}{c}\text { CFA }^{-} \\
\text {Final } \\
\text { Descriptor }\end{array}$ & $\begin{array}{c}\text { Factor 1 } \\
\text { Eigenvalue } \\
=12.06\end{array}$ & $\begin{array}{c}\text { Factor 2 } \\
\text { Eigenvalue } \\
=5.94\end{array}$ & $\begin{array}{c}\text { Factor 3 } \\
\text { Eigenvalue } \\
=4.04\end{array}$ & $\begin{array}{c}\text { Factor 4 } \\
\text { Eigenvalue } \\
=1.92\end{array}$ & $\begin{array}{c}\text { Factor 5 } \\
\text { Eigenvalue } \\
=1.39\end{array}$ \\
\hline Limitless & & & & & & \\
Vast & .80 & -.05 & .00 & -.02 & .04 & -.94 \\
Immense & .80 & .01 & .03 & -.04 & -.06 & -.82 \\
Infinite & .86 & .13 & -.03 & -.02 & -.02 & -.79 \\
Boundless & .86 & .10 & .00 & -.04 & -.05 & -.78 \\
Limitless & .89 & .17 & -.04 & -.02 & -.04 & -.78 \\
Transcendent & -- & -.01 & -.01 & .08 & -.09 & -.78 \\
\hline
\end{tabular}

Note: In the CFA, items were specified to load on only one subscale and, therefore, there are no cross-loadings to report. The CFA included only the items from the final version of the scale. Exploratory factor analysis was performed using principal components analysis with direct oblimin rotation and Kaiser normalization. 
Table 2. Means, Standard Deviations, and Intercorrelations for Scores on the LAMBI Scale and Measures of Godview, Religiosity, and Spirituality in Study 2

\begin{tabular}{lccccc}
\hline & Authoritarian & Benevolent & Limitless & Mystical & Ineffable \\
& $M=3.76$ & $M=5.31$ & $M=5.64$ & $M=5.17$ & $M=3.98$ \\
\multicolumn{1}{c}{ Variable } & $S D=1.55$ & $S D=1.55$ & $S D=1.32$ & $S D=1.30$ & $S D=1.67$ \\
\hline LAMBI subscales & & & & & \\
Benevolent & $.16^{* *}$ & -- & -- & -- & -- \\
Limitless & $.15^{* *}$ & $.64^{* * *}$ & -- & -- & -- \\
Mystical & .06 & $.46^{* * *}$ & $.62^{* * *}$ & -- & -- \\
Ineffable & .04 & $-.34^{* * *}$ & -.09 & -.02 & -- \\
\hline Godview & & & & & \\
Personal God & $.26^{* * *}$ & $.48^{* * *}$ & $.26^{* * *}$ & .06 & $-.28^{* * *}$ \\
Cosmic Force & $-.14^{* *}$ & -.01 & $.25^{* * *}$ & $.35^{* * *}$ & $.29^{* * *}$ \\
No view of God & -.05 & $-.47^{* * *}$ & $-.31^{* * *}$ & $-.14^{* *}$ & $.53^{* * *}$ \\
\hline Religiosity \& Spirituality & & & & & \\
Religious Fundamentalism & $.40^{* * *}$ & $.51^{* * *}$ & $.33^{* * *}$ & .09 & $-.38^{* * *}$ \\
Religious commitment & $.25^{* * *}$ & $.56^{* * *}$ & $.42^{* * *}$ & $.27^{* * *}$ & $-.30^{* * *}$ \\
God's Engagement & $.28^{* * *}$ & $.60^{* * *}$ & $.41^{* * *}$ & $.25^{* * *}$ & $-.38^{* * *}$ \\
Self/God overlap & .02 & $.39^{* * *}$ & $.38^{* * *}$ & $.35^{* * *}$ & $-.23^{* * *}$ \\
Individualistic spirituality & $-.21^{* * *}$ & .10 & $.17^{* *}$ & $.36^{* * *}$ & .10 \\
Quest religious orientation & -.02 & -.07 & .06 & $.20^{* * *}$ & $.33^{* * * *}$ \\
\hline
\end{tabular}

Note: ${ }^{* * *} p \leq .001 ;{ }^{* *} p \leq .01$ 
Table 3. Hierarchical Multiple Regression Analyses Predicting Political Conservatism, the Values of Benevolence, Universalism, and Affinity for Nature, and Belief in Reincarnation From God concept, God image, and LAMBI Subscales

\begin{tabular}{|c|c|c|c|c|c|c|c|c|c|c|}
\hline \multirow[b]{3}{*}{ Predictor } & \multicolumn{10}{|c|}{ Dependent Variable } \\
\hline & \multicolumn{2}{|c|}{$\begin{array}{c}\text { Political } \\
\text { Conservatism }\end{array}$} & \multicolumn{2}{|c|}{$\begin{array}{c}\text { Value of } \\
\text { Benevolence }\end{array}$} & \multicolumn{2}{|c|}{$\begin{array}{c}\text { Value of } \\
\text { Universalism }\end{array}$} & \multicolumn{2}{|c|}{$\begin{array}{l}\text { Affinity with } \\
\text { Nature }\end{array}$} & \multicolumn{2}{|c|}{$\begin{array}{c}\text { Belief in } \\
\text { Reincarnation }\end{array}$} \\
\hline & $\Delta R^{2}$ & $\beta$ & $\Delta R^{2}$ & $\beta$ & $\Delta R^{2}$ & $\beta$ & $\Delta R^{2}$ & $\beta$ & $\Delta R^{2}$ & $\beta$ \\
\hline Step 1 & $.11^{\text {***** }}$ & & $.16^{* * *}$ & & $.04^{* *}$ & & $.05^{* *}$ & & $.08^{* * *}$ & \\
\hline \multicolumn{11}{|l|}{ Controlling } \\
\hline God & & $.33^{* * *}$ & & .00 & & -.08 & & $-.14 \dagger$ & & -.26 \\
\hline Loving God & & $.44^{* * *}$ & & $.40^{* * *}$ & & $.15 \dagger$ & & .10 & & .03 \\
\hline Step 2 & $.03^{*}$ & & $.07^{* * *}$ & & $.05^{* *}$ & & .01 & & $.05^{* *}$ & \\
\hline Control & & $.32^{* *}$ & & -.09 & & $-.27^{*}$ & & -.17 & & $-.36^{* *}$ \\
\hline Goodness & & .02 & & $.40^{* * *}$ & & $.21^{*}$ & & .06 & & $-.26^{* *}$ \\
\hline Belonging & & -.14 & & .10 & & $.27 \dagger$ & & .16 & & $.32^{*}$ \\
\hline Step 3 & $.05^{*}$ & & .02 & & $.08^{* * *}$ & & $.14^{* * * *}$ & & $.10^{* * *}$ & \\
\hline Authoritarian & & $.14^{*}$ & & .04 & & -.05 & & $-.13^{*}$ & & -.02 \\
\hline Benevolent & & -.06 & & .21 & & .19 & & .00 & & .01 \\
\hline Limitless & & .14 & & -.09 & & $-.21 \dagger$ & & $-.27^{*}$ & & $-.24^{*}$ \\
\hline Mystical & & $-.25^{* * *}$ & & .08 & & $.30^{* * *}$ & & $.47^{* * *}$ & & $.39^{* * *}$ \\
\hline Ineffable & & .07 & & -.06 & & $-.16^{* *}$ & & -.09 & & $.14^{*}$ \\
\hline Total $R^{2}$ & $.19^{* * *}$ & & $.25^{* * *}$ & & $.17^{* * *}$ & & $.20^{* * * *}$ & & $.23^{* * *}$ & \\
\hline
\end{tabular}

Note: Variables were entered in three steps: God concept scales (Step 1), God image scales (Step

2), and LAMBI scales (Step 3). ${ }^{* * *} p \leq .001 ;{ }^{* *} p \leq .01{ }^{*} p \leq .05 ; \dagger p<.07$ 
Figure 1. Mean Scores for each LAMBI Subscale and unbelief (NoGod) by Latent Profile in Study 5

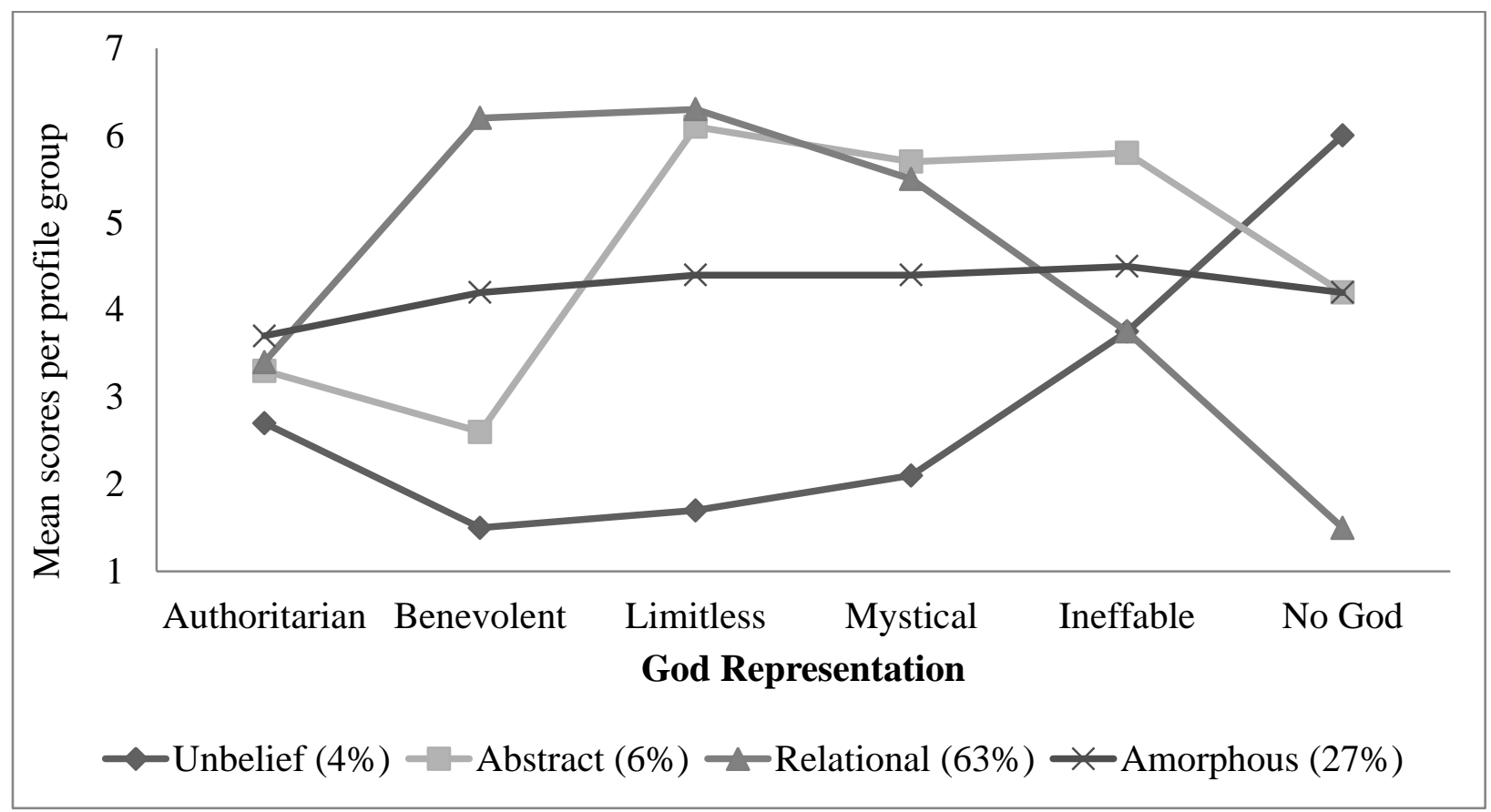




\section{Supplemental Material: Additional Content}

\section{Supplement to Study 1: Exploratory Factor Analysis}

Descriptive Statistics and Correlations between the LAMBI subscales. In accord with the results of our initial exploratory factor analysis, we computed mean scores and intercorrelations for each of the five LAMBI subscales. Authoritarian $(M=3.91, S D=1.51)$ was positively correlated with Benevolent $(M=6.03, S D=1.15), r(288)=.14, p=.020$, Limitless $(M$ $=5.94, S D=1.07), r(288)=.22, p<.001$, Mystical $(M=5.16, S D=1.30), r(288)=.14, p=$ .021 , and Ineffable $(M=3.43, S D=1.49), r(288)=.31, p<.001$. Benevolent was positively correlated with Limitless, $r(288)=.55, p<.001$, Mystical, $r(288)=.35, p<.001$, and negatively correlated with Ineffable, $r(288)=-.34, p<.001$. Limitless was positively correlated with Mystical, $r(288)=.48, p<.001$, but uncorrelated with Ineffable, $r(288)=-.002, p=.970$. Mystical was positively correlated with Ineffable, $r(288)=.15, p=.010$.

(We note here that earlier analyses had revealed that several descriptors did not meet certain typical criteria [e.g., low communalities, factor loadings less than .4, or high cross loadings] for inclusion in Study 1. Based on pilot studies, we discarded the following items prior to conducting our exploratory factor analysis: Majestic on the Limitless dimension, Mystifying and Oceanic on the Mystical dimension, and Hidden on the Ineffable dimension.)

Godview. To a certain extent, the factors of the LAMBI scale mirror the response options associated with a multiple choice item used in the 2010 General Social Survey (Godview variable; Smith, 2011). Thus, we also assessed belief in (a) a personal God, (b) an uninvolved creator, (c) not a person, but a cosmic force, (d) having no view, or (e) no belief. Because the descriptors associated with benevolent and authoritarian can be attributed to anthropomorphized entities, we expected that belief in a personal God would be associated with benevolent and 
authoritarian. We expected that the relatively more abstract descriptors of vastness (i.e., the Limitless adjectives) or energy (i.e., the Mystical adjectives) would be associated with belief in a cosmic force. Finally, we expected that the adjectives associated with Ineffable would be associated with a deist view of God as uninvolved or having no clear view of God.

Participant responses regarding views of God (Godview variable) allowed us to create a categorical variable: view of God as (a) a personal being $(n=173)$, (b) a cosmic force $(n=92)$, (c) an uninvolved creator $(n=18)$, or $(d)$ having no clear view of God $(n=5)$. Because only five participants said they had no clear view of God, we combined their responses with those who said that God was uninvolved $(n=23)$. The relative means are shown in Figure 1.

Figure 1. Mean Scores for each God Representation by Type (Personal Being, Cosmic Force, or Uninvolved Deity) in Study 1

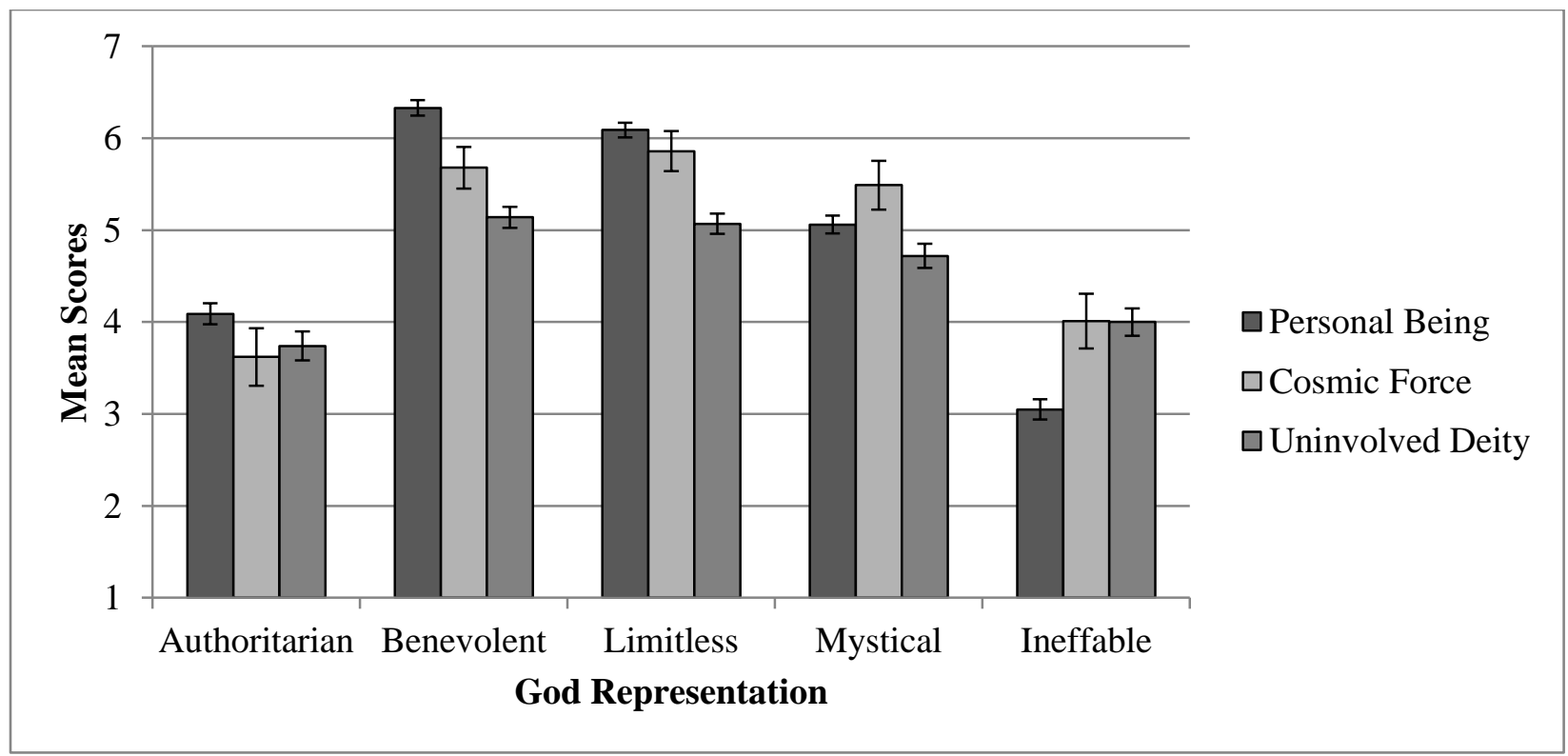

A mixed ANOVA was conducted with Godview Type as the between-person factor (i.e., personal, cosmic, uninvolved/ no view) and LAMBI subscale as the within-person factor. There was a significant interaction, Wilks Lambda $=.76, F(8,564)=7.58, p<.001, \eta^{2}=.13$ (Figure 1). Authoritarian was more closely linked with a view of God as a personal being rather than a 
cosmic force, $p=.048$; Benevolent was more closely linked with a view of God as a personal being rather than a cosmic force, $p<.001$, or an uninvolved deity, $p<.001$; Limitless was more closely linked with a view of God as a cosmic force, $p=.004$, or as a personal being, $p<.001$, rather an uninvolved deity. Mystical was more closely linked with a view of God as a cosmic force rather than a personal being, $p=.030$, or an uninvolved deity, $p=.031$. Ineffable was associated with a view of God as a cosmic force, $p<.001$, or an uninvolved deity, $p=.010$.

\section{Supplement to Study 3: Test-Retest Reliability of the Five Factor LAMBI Scale}

The means, standard deviations, and correlations for two time points, for each of the subscales, are provided in Table 3. The high correlations suggest that participants' representations of God across the two time points were consistent ( $r$ 's from .75 to .94). Furthermore, paired samples $t$-tests examining changes in scores indicated that all five subscales exhibit stability in their group means in that there were no significant changes. Thus, the LAMBI subscales have good stability and test-retest reliability.

Table 3. Means, Standard Deviations, Correlations, and Paired Sample T-Test Results for Each of the Five LAMBI Subscales, at Time 1 and Time 2, in Study 3

\begin{tabular}{|c|c|c|c|c|c|c|}
\hline \multirow[b]{2}{*}{ LAMBI Subscale } & \multicolumn{2}{|c|}{ Time 1} & \multicolumn{2}{|c|}{ Time 2} & \multirow[b]{2}{*}{$r$} & \multirow[b]{2}{*}{$t$} \\
\hline & $M$ & $S D$ & $M$ & $S D$ & & \\
\hline Authoritarian & 3.06 & 1.66 & 3.20 & 1.70 & $.85^{* * * *}$ & 1.53 \\
\hline Benevolent & 4.89 & 1.97 & 4.77 & 1.96 & $.94^{* * *}$ & $1.85^{\dagger}$ \\
\hline Limitless & 5.26 & 1.82 & 5.28 & 1.86 & $.92^{* * *}$ & .36 \\
\hline Mystical & 4.95 & 1.72 & 4.87 & 1.80 & $.85^{* * *}$ & .88 \\
\hline Ineffable & 3.97 & 1.85 & 4.17 & 1.90 & $.75^{* * *}$ & 1.51 \\
\hline
\end{tabular}

${ }^{\dagger} p=.067$ 


\section{Supplement to Study 5: Latent Class Analysis and Religious Group Differences}

Latent Class Analysis. We conducted a Latent Class Analysis using the 25 items from the LAMBI scale and three items assessing unbelief Table 5. Fit statistics for Latent Profile Analysis

\begin{tabular}{|c|c|c|c|c|c|c|}
\hline \multirow[b]{2}{*}{ Statistic } & & \multicolumn{5}{|c|}{ Number of Classes $(k)$} \\
\hline & & 1 & 2 & 3 & 4 & 5 \\
\hline AIC & & 31932 & 29992 & 29062 & 28760 & 28497 \\
\hline $\mathrm{BIC}$ & & 31995 & 30092 & 29199 & 28933 & 28708 \\
\hline $\mathrm{ABIC}$ & & & 30032 & 29117 & 28829 & 28581 \\
\hline LMR & & & 1916 & 925 & 311 & 270 \\
\hline$p$ & & & 0.00 & 0.00 & 0.09 & 0.00 \\
\hline Entropy & & & 0.98 & 0.92 & 0.92 & 0.83 \\
\hline \multicolumn{7}{|l|}{ Nfor each class } \\
\hline & Class 1 & & 973 & 59 & 59 & 59 \\
\hline & Class 2 & & 461 & 896 & 85 & 85 \\
\hline & Class 3 & & & 479 & 904 & 367 \\
\hline & Class 4 & & & & 386 & 509 \\
\hline & Class 5 & & & & & 414 \\
\hline \multicolumn{7}{|l|}{ Class identity } \\
\hline & Class 1 & & Relational & Unbelief & Unbelief & Unbelief \\
\hline & Class 2 & & Amorphous & Relational & Abstract & Abstract \\
\hline & Class 3 & & & Amorphous & Relational & Amorphous \\
\hline & Class 4 & & & & Amorphous & Relational \\
\hline & Class 5 & & & & & BLMI \\
\hline
\end{tabular}

Notes: Best fitting number of classes is in boldface. Unbelief $=$ high scores for Ineffable and

NoGod; Relational $=$ high scores for Benevolent, Limitless, Mystical; Abstract $=$ high scores for Limitless, Mystical, and Ineffable; Amorphous = little variability between mean scores of God 
representations; BLMI $=$ high scores for Benevolent, Limitless, Mystical, Ineffable. AIC $=$ Akaike information criterion; $\mathrm{BIC}=$ Bayesian information criterion; $\mathrm{ABIC}=$ adjusted $\mathrm{BIC} ; \mathrm{LMR}$ $=$ Lo, Mendel, and Rubin index.

In mixture modeling, statistics that suggest the optimal number of profiles/groups/classes are: the Akaike information criterion (AIC), the Bayesian information criterion (BIC), the adjusted BIC (ABIC), and the Lo, Mendel, and Rubin (LMR) index. These tests are used to compare pairs of models and lower values indicate better fitting models. A non-significant $p$ value suggests that the current model should be retained. The Entropy statistic indicates the certainty of accurate classifications, with larger values indicating greater certainty. The change statistics between $k$ and $k+1$ number of groups is central in the analysis, but it is also important to consider the number of individuals within each group (larger groups are better) as well as any theoretical implications in deciding the optimal number of profile groups. More information about LPA as a statistical procedure can be obtained on the Mplus website (www.statmodel.com) or from various papers (e.g., Muthen, 2002; Stankov \& Lee, 2016). We found that the best fitting model (in bold) yielded four profile groups as shown in Table 5 .

Religious group differences. We also conducted a multivariate ANOVA to investigate differences for each of the five LAMBI subscales and unbelief across three self-reported religious types: Religious, Non-religious, and SBNRs. There was a significant effect of Religious Group, $F(12,2852)=88.54, p<.001$; Wilks' Lambda $=.53$; partial $\eta^{2}=.27$. The relative means and standard errors for each of the God representations and NoGod, by religious type, are shown in Figure 3. 
Figure 3. Means scores for Authoritarian, Benevolent, Limitless, Mystical, Ineffable, and No God, by Religious Group, in Study 5

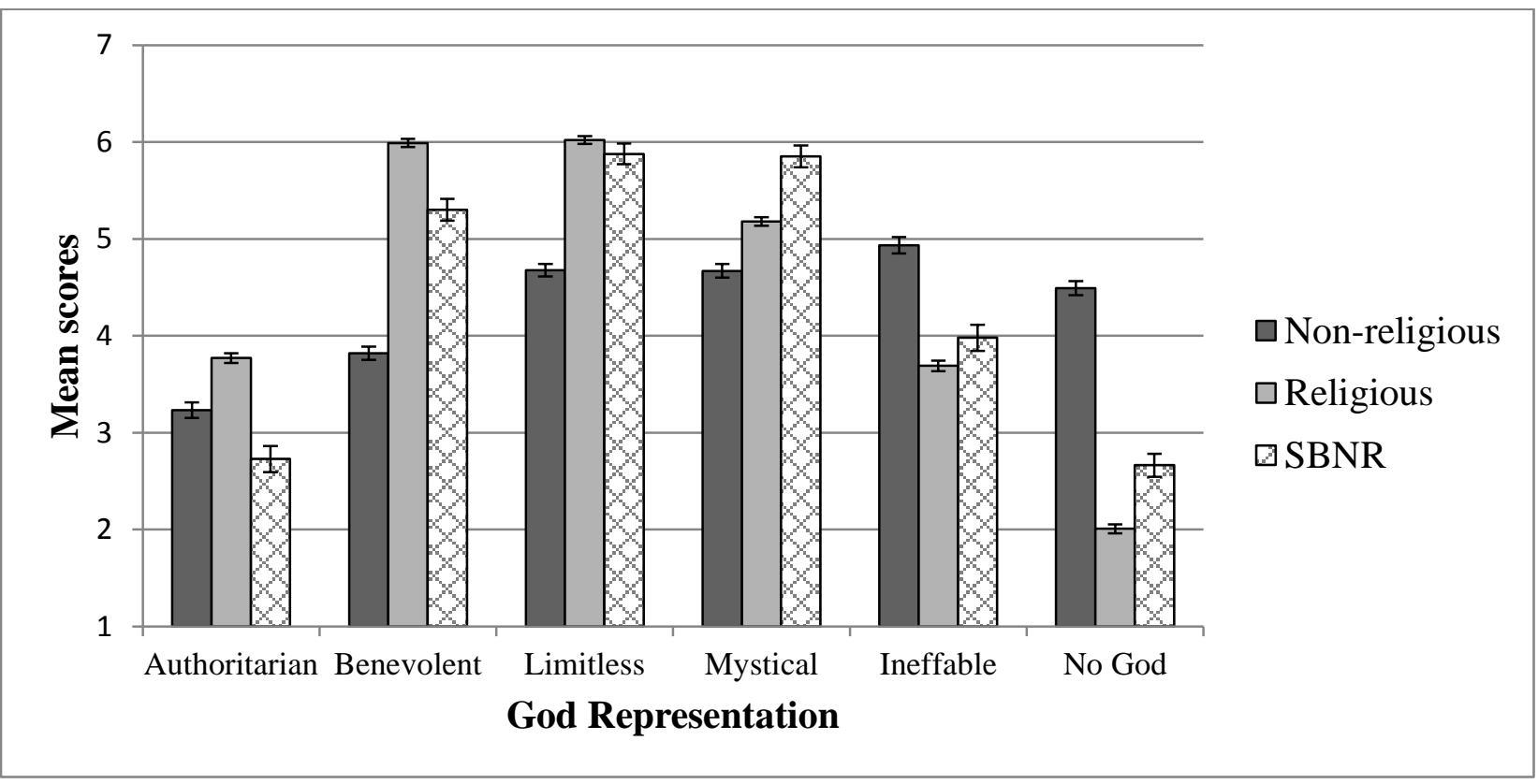

Bonferroni corrected tests revealed the following significant differences between types: (a) Authoritarian: SBNR < Non-religious, $p=.004$, and Religious, $p<.001$; (b) Benevolent: Non-religious < Religious and SBNR, $p$ 's < .001, and SBNR < Religious, $p<.001$; (c) Limitless: Non-religious < Religious and SBNR, $p$ 's <.001; (d) Mystical: Non-religious and Religious < SBNR, $p$ 's $<.001$, and Non-religious < Religious, $p<.001$; (e) Ineffable: Religious and SBNR < Non-religious, $p<.001$; and (f) No God: Religious < Non-religious and SBNR, $p$ 's $<.001$, and Religious $<\mathrm{SBNR}, p<.001$.

In sum, we found that four different response patterns (or clusters of God representations) emerge in thinking about the various attributes of God. However, response patterns seem to represent individual differences and do not align well with religious group identity. Instead, we found that the separate dimensions of the LAMBI scale are better suited to capture variability in the ways in which Religious, Non-religious, and SBNRs represent a God or a Divine Life Force. 


\section{Supplemental References}

Muthen, B. O. (2002). Beyond SEM: General latent variable modeling. Behaviormetrika, 29, 81117.

Stankov, L., \& Lee, J. (2016). Toward a psychological atlas of the world with mixture modeling. Journal of Cross-Cultural Psychology, 47, 249-262. 